\title{
5. Sociae
}

EISSN 2620-4975

ISSN 1410-3745

\section{INFOGRAPHIC: INFORMATION DELIVERY MEDIA IN PUBLIC RELATIONSHIP PRACTICES}

\author{
${ }^{1}$ Fajar Novianto, ${ }^{2}$ Marshelia Gloria Narida \\ ${ }^{12}$ Communication Science, Universitas Kristen Indonesia, Jakarta, Indonesia \\ Ifajarnovianto650@yahoo.com, ${ }^{2}$ gloriamarshelia@gmail.com
}

\begin{abstract}
This article discusses the process of applying infographic criteria by the Sub-Department of Law and Public Relations of the Directorate General of Horticulture (DG Horticulture) as a medium for delivering information to the public. The results of the study showed that there were nine criteria for the process of applying the standards in a collection of good quality infographics at Sub-Department of Law and Public Relations of the Directorate General of Horticulture before infographics could get disseminated to the public. Where in the nine criteria application process, each criterion explains how to focus the media on delivering information that is interesting and easily understood by the public.
\end{abstract}

Keywords: Infographics, Public Relations, Media, Information

DOI: $10.33541 /$ sp.v20i2.1444

Sociae Polites : Majalah Ilmiah Sosial Politik

Faculty of Social and Political Science, Universitas Kristen Indonesia

ISSN 1410-3745 print/ ISSN 2620-4975 online

Volume 20, Number 2 (July - December 2019)

Pages 127-144 


\section{Introduction}

The development of an organization or a company cannot separate from the function or role of the management of Public Relations (PR), which is very important to be able to build communication with the community. In general, the function or role of PR practitioners is to manage and maintain a useful and beneficial relationship between a company or organization and its public. One way of PR in maintaining relations with the community is to become a provider of information (publicity) that can be useful for the community and also the company. One function of public relations practitioners is to do advertising or usually also known as "public information" (Cutlip et al. 2011, 13). Publicity can be in the form of information about announcements about the opening of new businesses, launching new products, clarification of issues, and other information that has value to the public. Publicity takes the form of the press release, a magazine, brochure, speech script, or particular media which messages arranged and planned distributed to meet the public interest. Also, public relations need to be able to regulate the company's website and online media as a form of work and task in following the development of new information delivery tools.

In government agencies, public relations, or usually referred to as public affairs officials, have the main task of providing information (Cutlip et al., 2011, 468). The role has the objective of ensuring a good flow of information from the government to the community. Besides, according to Morissan (2008, 90), public relations practitioners have a function that is to help and disseminate information and explain the activities or policies carried out and made by the government to the public. In assisting the role and function as a conveyor of information, public relations practitioners need media that can help the process of the flow of dissemination. The media are used by PR to deliver data at the level of internal communication and also external communication. In external communications, public relations use several media, including newspapers, magazines, radio, and television. The rapid development of the era, which is proportional to technological advances, helps to change the communication process to become more advanced. The advent of the internet has become the most significant factor in improving the method of communication to be very broad and deep (Cutlip et al., 2011, 287).

However, this convenience also has the disadvantage that much information disseminated does not have credible sources. Therefore, government public relations as a trustworthy provider and provider of data need to keep up with the times and use the internet. Besides, government public relations also has a challenge that is the source of information on the internet also has many credibilities. It makes government public relations take part in using infographics as a form of adopting ideas and practical things in conveying information on the internet. Government public relations use infographics as a medium to send information that is interesting and easily understood by the public.

Infographics are one of the media that can be used by communicators to convey information. Infographics come from the word infographics in English, which stands for information and graphics, refers to the understanding of creative content consist of a combination of colors, information text, graphics, and images/photos (Kemkominfo, 2018, ix). The combination intends to facilitate the delivery of information to everyone who sees to capture the information provided through data visualization. 
In government agencies, infographics are also often used to deliver information to the public. Infographics in government divide into four categories of content types, namely: Daily Issues, Government Programs, Public Education and Information, and about Indonesia (Kemkominfo 2018, 3). Daily infographic information has the aim of conveying the most up-to-date information or topics that are currently hot in the community. Meanwhile, on education infographics and public information, the objective is to provide guidance information about something or show a schedule. Then in infographic programs, the government has the aim to socialize government programs, convey important information, and also program guidelines established by the government. In the type of infographic about Indonesia contains engaging entertainment and information (Kemkominfo 2018, 3).

In the process of making or compiling infographics, it is necessary to research in advance so that the sources of information obtained can account for it. There are many processes for making infographics ranging from color selection, actual and up to date facts, pictures, and others. Identify the audience who receive messages or information to convey through infographic media is one of the essential processes, given in the character, background, and social that can affect the ability to receive information. In the book Tips for Making Cool Infographics published by the Ministry of Communication and Information of the Republic of Indonesia (Kemkominfo) in 2018, states there are criteria for content standards in the preparation of good quality infographics. The following are of good quality infographic criteria, according to the Ministry of Communication and Information (2018, 2). Namely; Orientation of infographic objectives, based on research and sources that can account for and date of production as a reference actuality, relevance to the needs of readers, harmonious and attractive visual structure, readability, has an element of persuasion, straightforward, consistency with brand guidelines and ease of sharing.

Based on what state above, infographics can bring change and become new and vital things in the world of public relations practices in conveying messages to the public. Changes and new ideas also include how public relations should be able to make their infographics, and this is because infographics in the practice of public relations are not just putting information and attractive as an infographic on journalism. However, infographics must be able to bridge companies or government agencies with the public or the public. It also has an impact on public relations to manage and also use its infographic-making application.

In the echelon, I work unit within the Indonesian Ministry of Agriculture, the Directorate General of Horticulture (Directorate General of Horticulture), public relations practitioners provide services to the public by using infographics as a medium for delivering infographics. Based on Regulation of the Minister of Agriculture Permentan 20 of 2016 Job Description Echelon IV Work Unit, Legal, and Public Relations Subagraph pages 36-42. It states that the Legal and Public Relations Subag of the Directorate General of Horticulture has the main task of preparing material information and documentation, making material, and public information services in the horticultural sector and to conduct documentation of public information in the agriculture field. In this case, compiling infographics is the primary duty of horticultural public relations as the provider and compiler of general information.

Infographics compiled by the public relations directorate general of Horticulture spread through social media Facebook (Directorate General of Horticulture) and 
Instagram owned by the Directorate General of Horticulture (@ ditjenhorti). Examples of infographics that have been made by the Directorate General of Horticulture public relations and distributed through social media are infographics about the fermentation of kenikir extract as control of plant-disturbing organisms (OPT) to combat insect pests that occur. The infographic objective of the kenikir extract, which compiles, was to guide the method of fermentation of kenikir extract and the contents contained in kenikir to farmers and communities who owned or planted horticultural commodity crops.

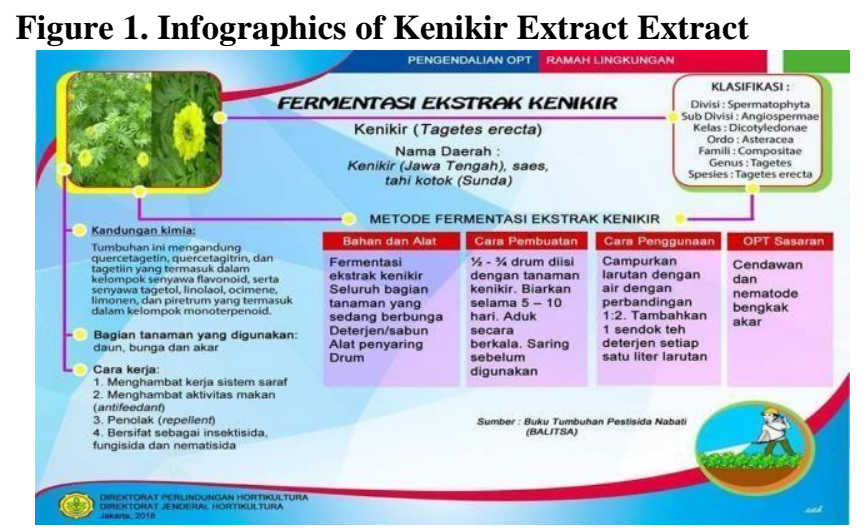

The previous research that was used by the author as a reference and consideration to get a different perspective of the prior writer and various research topics is a thesis entitled. "Infographics Strengthening Government Public Relations Reputation through a Single Narrative Socialization of Economic Policy Package" compiled by Lisa Adhrianti, Program Communication Department, Bengkulu University. The research aims to find out how infographics can strengthen the reputation of the public relations of the government by the Special Task Force (SATGASUS) Government Public Relations (GPR). At the same time, in this study, the writer wants to find out how the compilation of infographic content compiled by the public relations directorate general of Horticulture as a part of the public relations function is doing delivery of information to the public. Therefore, in this study, the authors wanted to research the process of applying infographic criteria compiled by the public relations directorate general of Horticulture.

The author would like to focus on research on how the process of applying the criteria of the Subagencies of Law and Public Relations of the Directorate General of Horticulture in compiling infographics, how the Subagits of Law and Public Relations of the Directorate General of Horticulture get information how to research. It will become a piece of information that will raise, how the preparation of texts, selection of pictures or photographs, and application used by public relations horticulture in compiling infographics. The compilation of infographic content is the problem in research. Besides, the appointment of themes about infographics by public relations practitioners is due to a study conducted by Dr. Albert Mehrabiann, a psychology professor from the University of California, Los Angeles, who said that humans are more receptive to visual communication (Arifin et al., 2015, 2). 
This article specifically discusses how the process of applying infographic criteria as a medium for delivering information on the practice of Public Relations at the Directorate General of Horticulture. This article specifically discusses how the process of applying the criteria in the initial preparation of infographics to infographics can be disseminated by the Law and Public Relations subgraph of the Directorate General of Horticulture to the public. The purpose of this article is to find out how infographics can be a medium for delivering information that is used by public relations practitioners.

\subsection{Horticulture Directorate General}

The Directorate General of Horticulture is an Echelon I work unit within the Ministry of Agriculture of the Republic of Indonesia established by Presidential Regulation of the Republic of Indonesia Number 92005 concerning Position, Duties and Functions of Organizational Structure and Work Procedures of the Ministries of the Republic of Indonesia and Presidential Regulation of the Republic of Indonesia Number 10 of 2005 concerning Organizational units and Work Procedures of the Echelon I of the State Ministries of the Republic of Indonesia as amended by Presidential Regulation of the Republic of Indonesia Number: 15 of 2005 , which is then further elaborated in Regulation of the Minister of Agriculture Number: 299 / Kpts / OT.140 / 7/2005 jo 11 / Permentan / OT.140 / 2/2007 concerning Organization and Work Procedure of the Ministry of Agriculture CQ the Directorate General of Horticulture and Regulation of the Minister of Agriculture Number: 341 / Kpts / OT.140 / 9/2005 jo 12 / Permentan / OT.140 / 2/2007 concerning Completeness of Organization and Work Procedures of the Ministry of Agriculture in this case the Directorate General of Horticulture which is currently established

\subsection{Infographic}

An infographic is an image that gives us information. Infographics can be in the form of graphs, charts, maps, and other things. Infographics make information easy to understand. We can see infographics everywhere, and infographics can be in books, newspapers, television, websites, posters, and others (Oxlade, 2014, 4). An infographic contains an image, symbols, illustrations, statistical data, and attractive designs.

Meanwhile, according to Smiciklas $(2012,3)$, infographics are defined as visualizing data or ideas that try to convey complex information to the audience in specific ways and can be easily understood or easily understood. Infographics consider being one of the effective media in communicating and visualizing complex data or information. The use of infographics used by many international and national institutions, such as the World Bank, at the international level to the Ministry of Communication and Information at the national level (Satria, 2016, 5). The effectiveness of infographics lies in good data visualization so that it can influence the reader to want to capture in detail the intent of the infographic read.

\subsection{Infographic Formulation}


Infographics made to make it easier for the public or readers to be interested and easy to understand. Therefore infographics have several criteria or steps used as a reference for the preparation of quality infographics. The following criteria or steps in preparing good quality infographics:

- Objective-oriented infographics

The resulting infographic results must orient towards each content type of goal. The purpose of government content generally divides into five things, namely to provide information and guidance, socialize, entertain, and provide actual information.

- Research, Sources and Time of Production

Infographics produced need to go through a research process from accountable sources. Data sorting carried out using a statistical-based approach with definite objectives. Data sorting uses a logical method. It has comprehensive and accurate information, content contains references that can be validated sources of licenses/permits for the use of assets, obtained from the internet, and the list includes the date of production so that readers know whether the information is still valid.

\section{- Relevant to Reader Needs}

The infographic results produced must be consistent. Infographics must be actual, following current reality, up to date with the needs of existing readers, offering new information or the latest delivery techniques, and supporting illustrations or drawings.

- Visual structure

Infographics produced must have an excellent visible structure. Infographics need to have a visual balance, a combination of symbols, illustrations, images, fonts that match the style, logos, pictures, images, fonts according to the character of the topic display, color palette, a color selection that is easily absorbed by the eye, design elements with proportions accurate, structured presentation on a neat and professional grid and has a good composition of audiovisual elements.

- Readability

The infographics produced can be easily read and understood. The text in the infographic does not need to long, the font size is not too small, so it is difficult to read (minimum font size is 9 points), the infographic uses excellent and correct Indonesian. There is an ideal distance between fonts (not too tight).

- Persuasion Infographics produced need to have an element of belief to attract readers. The persuasion element can use in infographic titles, where the selection of infographic titles can direct the reader to continue reading infographics and arouse curiosity. 
The part of persuasion can also get used at the level or visual side of infographics.

- Simple (Simplicity)

The infographics produced need to be straightforward or directly to the point that they want to explain. Infographics need to have a plot that is not ambiguous or in order under the flow of exposure, then have a central idea that is the focus, does not cause bias, ambiguity, and misunderstanding, and needs to choose terms that are easily understood by everyone.

- Brand Guideline Infographics produced must be by the brand guidelines and not violate existing regulations. Infographics need to have characteristics that are consistent with the brand or the company.

- $\quad$ Easy to Share (Shareability)

Infographics that have produced must easily share on websites, various media platforms, especially digital media or social media (Kemkominfo 2018, 2-8). Jason Lankow also explained some of the processes for compiling infographics before becoming an effective data visualization requires the collaboration of several steps, namely:

- The Creative Brief and Ideation

It is the initial foundation of the infographic preparation project. At this stage, the compiler of the infographic makes summary ideas and the creation or selection of what information will raise to use as a guideline in preparing infographics.

- Research and Data Analysis

In this stage, the information that previously formed was retested and analyzed data so that the information contained in the infographic could account for as accurate.

- Content Creation

Information that has created and tested or analyzed then formed into dense information content, and the language is easy to understand so that the audience intended or chosen by the infographic compiler can easily absorb well the information conveyed.

- Design and Data Visualization

At this stage, the infographic compiler makes a template or infographic mode container created with the help of infographic-making tools such as I chart, Pixlr, Canva, etc. After that, the information made into information content that will be raised and then put into an infographic template. Information content that placed in an infographic template can be in the form of an image, animation, statistical data, etc.

- Distribution 
The final stage is the purpose of preparing the infographic, namely, allocation or distribution of infographics through social media, mass media, banners, print media, etc. In dissemination through social media, infographics must be accordance with the social media platform that will get used because each social media has a different picture size with the others (Lankow 2012, 4).

\section{Research Method}

In this article, the research method used is a descriptive qualitative method. Descriptive qualitative research intended to describe and describe the phenomena that exist, both natural and human engineering, which pay more attention to the characteristics, quality, and interrelations between activities. Besides, descriptive research does not provide treatment, manipulation, or alteration of the variables studied but instead described an as-is condition. The only procedure given is the research itself, which done through observation, interviews, and documentation (Nana Syaodih, 2011, 73). The descriptive qualitative method is used by researchers so that researchers can describe and explain in detail how the process of applying infographic criteria is carried out by the Legal and Public Relations Subagency of the Directorate General of Horticulture.

In this research article, the subject of the research of the researcher is the public relations practitioner of the Directorate General of Horticulture, who regulates and compiles infographics, which referred to as research informants. To get a research informant that matches the research discussion, the researcher uses the informant taking technique. The purposive sampling technique is a technique that provides specific considerations (criteria) in the sampling (Fitrah and Luthfiyah, 2017, 161). In this research article, the research informants are as follows:

- Mr. Rico as Head of Legal and Public Relations Sub Division of the Directorate General of Horticulture

- Mr. Alif, a staff member of the Law and Public Relations Directorate General of Horticulture as the infographic organizer

- Kristrianto Dimas and Septiani Ayu as the internship students who became the Data Triangulation in this study.

\section{Results and Discussion}

The findings obtained by researchers in knowing how the process of applying infographic criteria as a medium for delivering information in the practice of public relations at the Directorate General of Horticulture is the researcher explain or describe through the description of each criterion and other results related to the research.

\subsection{Infographic as Information Delivery Media}

Infographics as data visualization media become one of the media to convey information that can be said to be easy to read and also enjoyable to continue reading. 
Interest in infographics caused by the contents of the infographic content itself. In the contents of the content, infographics contain data in the form of images, data charts, graph data to a map. The materials of the content make the public or public interested to see. But keep in mind that infographics are not just about how much and how interesting an image or visualization of data it is. Infographics must also be made into a medium to convey information that is concise, concise, and clear.

If we look at what Oxlade $(2014,4)$ found, infographics are an image that gives us information. Infographics can be in the form of graphs, charts, maps, and other things. Infographics make information easy to understand. This is the same as what was stated by one of the research informants. That infographics are media in describing data in a more concise, detailed, and valid way. The use of numbers in a chart makes information shorter.

\subsection{Objective-oriented Infographics, The Creative Brief, and Ideation}

The main criteria in the process of applying infographic criteria proposed by the Ministry of Communication and Information are the criteria for determining objectives and being the basis for composing an infographic. It is on this main criterion that the Horticultural Law and Public Relations Subag section negotiates ideas and chooses what information will be used as information content material in the infographics to compile. In the results of the analysis, Mr. Rico, as the Head of Law and Public Relations of the Directorate General of Horticulture, said that the Horticultural Law and Public Relations Subag always gathered in a meeting to determine what infographics would be raised, discussing what issues were hot. An example of a question posed by Mr. Rico is the issue of action by farmers wasting chili. In this case, the deliberation related to the problem is to make information to the public to be able to use chili into other useful processed products.

The ideas that are present and become a decision not always obtained from $\mathrm{Mr}$. Rico as the Head of Subdivision. However, these ideas also come from staff who are part of the Sub-Department of Horticulture Law and Public Relations. Mr. Rico also stated that later after the concept of selecting the topic of information obtained, the students and interns would be given guidance to be able to do practical work in making infographics. Mr. Alif stated the same thing as staff of Subah Hukum and Horticulture Public Relations to pay attention to the selection of information content so that it has benefits to the community. Likewise with Dimas and Septi, who also shared similar things with the previous research informants. Dimas and Septi revealed that in addition to getting ideas from the staff who manage the infographics of the Law and Public Relations Directorate, as apprentice students also provided insights for input on existing issues but through joint discussions with staff who lead infographics.

In this case, what stated by the research informants is related to the criteria and preparation process proposed by the Ministry of Communication and Information and Lankow, which says that the infographic results produced must be oriented to objectives of the type of content. The purpose of government content is generally divided into five things, namely, to provide information and guidance, socialize, entertain, and provide actual information (Kemkominfo, 2018, 2-8). It also refers to one of the compilation 
processes, according to Lankow $(2012,4)$ The Creative Brief and Ideation, which at this stage is the initial foundation of the infographic preparation project. At this stage, the compiler of the infographic makes a summary of ideas creation or selection of what information they raised to get used as a guideline in preparing infographics.

\subsection{Research, Source and Production Time (Kemenkomifo)}

At this stage, all information that will get used as information content has several conditions before it can get raised into infographics. According to Kemenkoinfo $(2018,28)$, infographics produced need to go through a research process from accountable sources. Data sorting get carried out using a statistical-based approach with definite objectives. From what was stated by the Ministry of Communication and Information, there are three requirements, namely information coming from sources that can get accounted for, information obtained must go through a research process. Data needs to include the date of production.

This relates to the stage proposed by Lankow $(2012,4)$. In this stage, the information that previously formed, re-tested and analyzed data so that the information contained in infographics can get accounted for accuracy. In the results of data analysis conducted by researchers, researchers found an association with what was stated by Mr. Rico in his interview. Information content in infographics of the Directorate General of Horticulture Law and Public Relations Subagraph obtained from each division in the Directorate General of Horticulture. Namely, regarding the cultivation of fruits collected from the Directorate of Fruits and Floriculture, regarding vegetables and medicinal plants, the information came from the SDO Directorate and information about seeds with certified quality coming from the Directorate of Seed and others. Besides that, the same thing also stated by Mr. Alif. Namely, that in addition to getting information from each division that conducted the study, the Sub-Department of Law and Public Relations of Horticulture also obtained data on export and import related data from the Central Statistics Agency (BPS).

\subsection{Relevant to Readers Need}

According to the Ministry of Communication and Information (2018, 2-8) stated that the results of infographics produced must be relevant. Infographics must be actual, following current reality, up to date with the needs of existing readers, offering new information or the latest delivery techniques, and supporting illustrations or drawings. In the results of the analysis related to the relevance of the information to the needs of the reader, Mr. Rico stated in his interview that the Sub-Department of Horticulture Law and Public Relations always hold meetings or discussions in advance to discuss issues that are currently hot in the community.

Examples of issues raised are when farmers take action to dispose of chilies. At that time, public relations meetings meet with these issues and then make information related to the use of chili as other preparations. This statement stated in the results of interviews with Mr. Rico and Mr. Alif. In the analysis results, the researcher also found points that were relevant to the needs of readers. It stated that the Sub-Law of 
Horticulture and Law also carried out requests for information in the form of infographics obtained through comments on the social media of the Directorate General of Horticulture.

Figure 2. Infographics about chilies put forward by Mr.Alif.

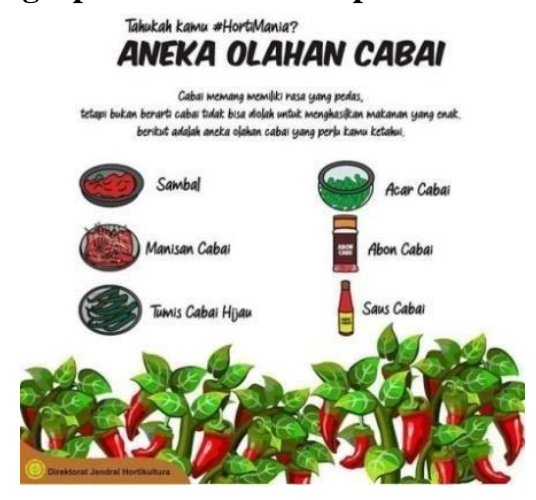

\subsection{Visual Structure and Design and Data Visualization}

In the manufacturing process, a useful infographic is an infographic that has a visual structure that is images, text, color, design, and others. Besides, this stage will also present a helper application used by the Sub-Department of Law and Public Relations of the Directorate General of Horticulture in compiling infographics. In what has been stated by the research informant, Mr. Alif, the first element that makes infographics interesting is the use of not too many colors. In infographics, the use of the right colors is black and white; this is because these two colors become colors that are attached to the memory of the brain of the reader. He also stated that the use of many colors in infographics makes it lose its concentration and baffle the reader. As a result, the reader is not interested in continuing to see or read infographics.

Regarding the color of the informant's researchers, Dimas and Septi also suggested that the right colors in infographics are not many colors and contrast with other colors. When infographic background colors are dark, then using colors that are not too bright is the right choice. Besides, the Directorate General of Horticulture infographics also had the color characteristic of a yellowish-green color, which means the maturity of a fruit or the color of fresh fruit.

In the analysis of interview data, the researchers also found that in the text (font), a useful infographic is an infographic that does not have more than three types of font types. The use of 1-2 font types is the limit of using a proper font type in infographics - the same thing stated by other informants researchers related to text and fonts. The information contained in the infographic text needs to have spaces that are not too close together. Then in terms of font types, informants who carry out their duties as compilers of infographics utilize one of the websites to download font types, which is Dafont.com.

In the stage of compiling infographics of the Law and Public Relations Subagencies, the Directorate General of Horticulture uses supporting applications such as Canva, Corel Draw, Adobe Photoshop, and Adobe Illustrator. The informant also 
explained several things about the form used. In the use of Canva, it stated that the helper application is an online application that has almost 60,000 templates that can get used immediately. In Corel Draw, Adobe Photoshop and Adobe Illustrator are applications that compile infographics with no models that can get used, which means the preparation of infographics starts from an empty template that we form or arrange themselves (manually) to the end.

The above relates to the process of Visual Structure according to the Ministry of Communication and Information and Design and Data Visualization, according to Lankow, namely that the infographics produced must have an excellent visual structure. Infographics need to have a visual balance, a combination of symbols, illustrations, images, fonts that match the style, etc. Besides, this also relates to the preparation process proposed by Lankow $(2012,4)$ namely Design and Data Visualization, that is, at this stage, the infographic compiler makes a template or infographic mode container created with the help of infographic-maker tools such as I chart, Pixlr, Canva, etc.

Figure 3. Process of Making Infographics Using Corel Draw and Adobe Illustrator.
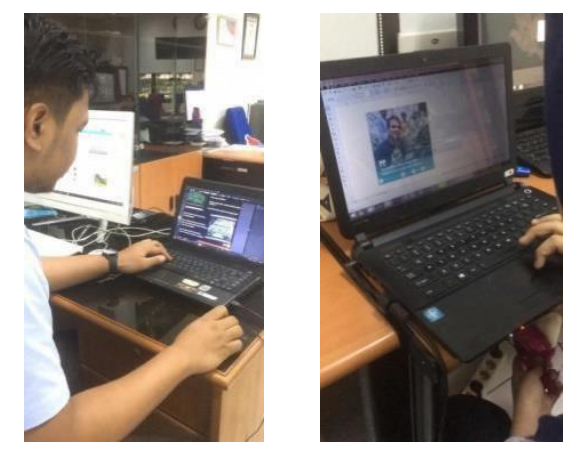

\subsection{Readability and Content Creation}

The infographic discusses how information is available so that it can be read well and can be understood. The infographics produced can be easily read and understood. The text in the infographic does not need to belong. The font size is not too small, so it is difficult to read (minimum font size is 9 points), the infographic uses excellent and correct Indonesian. There is an ideal distance between the fonts (not too tight) (Kemekominfo, 2018, 2- 8). The same thing also mentioned by Lankow (2012, 4), which is at the Content Creation stage, wherein the information that created and tested or analyzed then formed into dense information content. The language is easy to understand so that the intended audience or chosen by the compiler of the infographic can easily absorb well the information conveyed.

In this stage, the informants, namely Mr. Alif, Dimas, and Septi, stated that the use of color in text or useful information is the color that can be absorbed easily by brain memory that is not using many colors. Then the use of text types (fonts) is not too much. Just use two types of fonts in one infographic. Even though the text in an infographic looks simple, it is an exciting element and makes the infographic reader comfortable reading. Besides, the research informant, Dimas, also revealed that when 
there are words that are difficult to understand, such as exact words, they need to be searched for with other words and replaced or look for meanings of these words and explain them in infographics. This is because the purpose of infographics is to visualize data from information.

Figure 4. infographic with the type of text (font) and scientific words

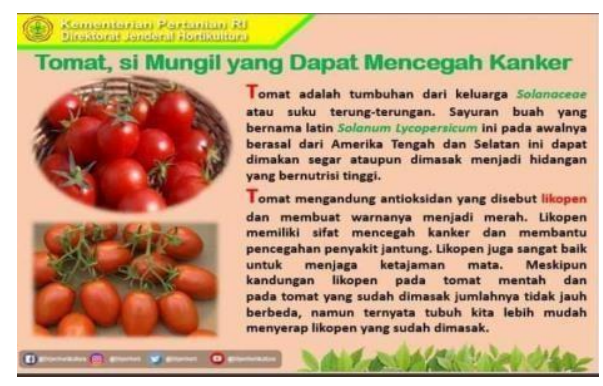

\subsection{Persuasive}

In the results of the analysis of researchers' interview data with the informant, there are points or points of conversation relating to the Persuasion point. Mr. Alif stated that the element that must get considered is the exciting element in infographics. Appealing infographics are infographics that do not have much color in them so that the reader does not lose interest in reading because too much is present in the infographic and makes the concentration disappear. A useful infographic is a simple infographic without eliminating exciting elements in it.

Mr. Alif said that he had made infographics that attracted people's attention and were spread through social media Twitter until the State Palace's Twitter account tweeted DG Horticulture's posts. Besides, Septi, as an apprentice student, also pointed out that one of the infographics compiled was also one of the most disputed posts. The infographic contains information about black-spotted bananas that are healthier and can increase the body's immune cells and fight cancer. The infographic has several likes and comments that are high enough that one comment asks whether the information a hoax or not. Still, it immediately explained that the information came from many sound sources.

What was revealed by the research informants related to what was stated by the Ministry of Communication and Information and Lankow is that the infographics produced need to have an element of persuasion to attract readers? The persuasion element can get used in infographic titles, where the selection of infographic titles can direct the reader to continue reading infographics and arouse curiosity). The part of persuasion can also get used at the level or visual side of the infographic (Kemkominfo, 2018, 2-8). 
Figure 5. The infographic contains unique information

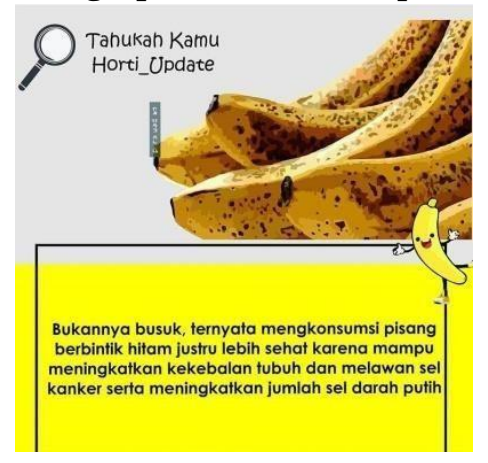

\subsection{Simplicity}

In infographics, it is necessary to be straightforward or to point out important points in the information - the infographics produced need to be direct or directly to the point that they want to explain. Infographics need to have a plot that is not ambiguous or following the flow of exposure, then have a central idea that is the focus, does not cause bias, ambiguity, and misunderstanding, and needs to choose terms that are easily understood by everyone (Kemkominfo, 2018, 2-8).

In the results of the analysis of the data obtained, the informants stated things that related to the straightforward criteria in infographics. The research informant said that infographics are a way to describe what the Horticultural Law and Public Relations Subagency wants to convey in a more concise, detailed, and valid manner.

\subsection{Brand Guideline Compatible}

The next element explained that infographics need to be following the Brand. The guideline, Infographics produced must be following the brand guidelines and not violate existing regulations. Infographics require characteristics that are consistent with the brand or the company (Ministry of Communication and Information, 2018, 2-8). In the interviews with the research informants, namely Mr. Rico, Mr. Alif, and Dimas stated that the infographics compiled by the Horticultural Legal and Public Relations Subag gave a logo or watermark on the Directorate General of Horticulture. The logo or watermark got provided so that when a person is claiming the infographic can get prosecuted and become evidence of patent infringement. Even so, Mr. Alif also explained that there were several infographics created by internship students who did not include logos or watermarks; this he pointed out because he argued that as a publicist in government agencies, the task was also to provide knowledge to the public. This is certainly different from what has been stated by Mr. Rico as the Head of Horticulture Law and Public Relations, who is the leader of Mr. Alif.

Figure 6. Logo of the Director-General of Horticulture 


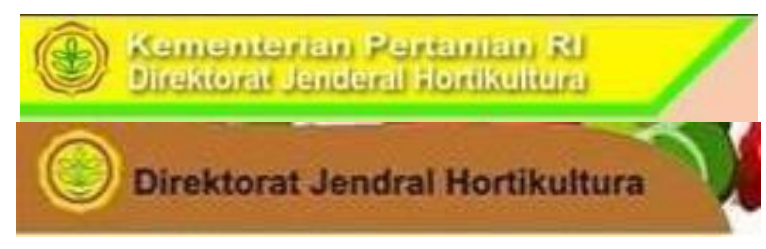

\subsection{Shareability and Distribution}

In the criteria and the final stage of composing infographics, it was stated by the Ministry of Communication and Information and Lankow, the infographic distribution or distribution process. Infographics that produced can get easily shared on websites, various media platforms, especially digital media or social media (Kemkominfo, 2018, $2-8)$. It also relates to the drafting process proposed by Lankow (2012,

4), i.e., distribution or distribution of infographics through social media, mass media, banners, print media, etc. In its dissemination through social media, infographics must be following the social media platform that will get used, because every social media has a different picture size with the others.

Both of the above contained in what was stated by Mr. Rico. Dimas. A similar case with the distribution indicated that when the infographic has completed, then immediately posted on social media, but through the process of discussion again so that information can review. Likewise, with what Dimas stated as an internship student. After the informant has finished working on the infographic, it will send to the staff of the Legal and Public Relations Subagencies that manage the infographic. If the information is correct and engaging, then the infographic will be loaded or posted on social media such as Facebook, Instagram, and Twitter.

\subsection{Diffusion Innovation Theory}

Based on the level of readiness in accepting new ideas or objects, according to Everett M. Rogers, the Directorate General of Horticulture is included in the early adopter group. Everett M. Rogers stated that the initial adopter group was local figures (less cosmopolitan than innovators), usually of high level as opinion leaders in the social system. In this case, stated by the two research informants,

The Directorate General of Horticulture occupies a place as a local figure and also an opinion leader in the social system that is as one of the government agencies that is the spokesperson in bridging the government and the people. The informant also stated that the Directorate General of Horticulture participated in optimizing the use of infographics in the social media of the Directorate General of Horticulture. It certainly relates to the theory used by researchers, where innovation diffusion theory assumes about how individuals and organizations adopt a new idea, practical thing, or object. The Directorate General of Horticulture took the use of infographics in social media as a new form in optimizing the delivery or dissemination of information to the broader community. 


\section{Conclusion}

Directorate General of Horticulture Infographics prepared through a process of applying quite a lot of criteria, to help the preparation so that the infographics that get compiled can have proper quality criteria. Termination and discussion phase is the first stage of the process of applying infographic criteria as a medium for delivering information. At this stage, the Legal and Public Relations Subag team all gather in a discussion to negotiate issues that will get raised on infographics. The second stage is conducting research and analysis of information material. In this case, the Legal and Public Relations Subag section of the Directorate General of Horticulture used to obtain sources from each division in the Directorate General of Horticulture and also obtain information from other reliable sources, one of which was the Central Statistics Agency (BPS).

In the third stage, the information raised in the form of infographics must be relevant to the needs of the reader. Infographics must bring up to date and current issues or news among the public. The fourth stage is designing and visualizing data through visual structures, namely images, text, color selection, and others. In the fifth stage, the Legal and Public Relations Subag section of the Directorate General of Horticulture used to use Canva, Corel Draw, Adobe Photoshop, and Adobe Illustrator as infographic-making applications. In the sixth stage, the Directorate General of Horticulture infographics also provides explanations or pronouns on scientific words that are rarely known to make it easier for the public to understand.

In the seventh stage, in each infographic compiled, the information provided contains unique information that is rarely or not yet known by the broader community as an element of persuasion that attracts the community. In the eighth stage, infographics can not get separated from the straightforward part (simplicity). In the Directorate General of Horticulture infographics, the Legal and Public Relations Subag Team provides the Directorate General of Horticulture logo on each infographic compiled. The final stage in the process of applying infographic criteria is to share or distribute infographics through various social media of the Directorate General of Horticulture, such as Facebook, Twitter, and Instagram. The obstacle was present during the infographic process using a PC or laptop. It then gets sent to the Directorate General of Horticulture Subag's Law and Public Relations staff for further discussion. 


\section{BIBLIOGRAPHY}

\section{Books}

Anggito, Albi dan Johan Setiawan. 2018. Metodologi Penelitian Kualitatif. Sukabumi: CV Jejak.

Ardianto, Elvinaro. 2010. Metodologi Penelitian untuk Public Relations: Kuantitaif dan Kualitatif. Bandung: Remaja Rosadakarya Bandung.

Arifin, Yulyani., Michael Yosep Ricky, dan Violitta Yesmaya. 2015. Digital Multimedia. Bina Nusantara: Jakarta.

Bogdan, R.C., dan Biklen, S.K. 1982. Qualitative Research for Education: An Introduction to Theory and Method. Boston: Allyn and Bacon. Inc.

Bungin, Burhan. 2011. Penelitian Kualitatif. Jakarta: Kencana Predana Media Group. Cangara, Hafied. 2006. Pengantar Ilmu Komunikasi. Jakarta: Raja Grafindo Persada. Cutlip, Scoot M., Allen H. Center, dan Glen M. Broom. 2011. Effective Public Relations, Edisi Kesembilan. Jakarta: Kencana.

Danim, Sudarwan. 2002. Menjadi Peneliti Kualitatif, Bandung: Pustaka Setia.

Daymon, Christine., dan Immy Holloway. 2008. Metode-metode Riset Kualitatif: dalam Public Relations dan Marketing Communications. Yogyakarta: Penerbit Bentang.

Denzin, Norman K., dan Lincoln, Yvonna S. 2005. The Sage Handbook of Qualitative Research: Third Edition. United States of America: Sage Publications.

Fitrah, M. dan Luthfiyah. (2017). Metode Penelitian: Penelitian Kualitatif, Tindakan Kelas \& Studi Kasus. CV Jejak: Sukabumi.

Hesse-Biber, Sharlene Nagy., dan Patricia Leavy. 2011. The Practice of Qualitative Research: Second Edition. United States of America: Sage Publications.

Jefkins, Frank. 1992. Public Relations (Edisi Keempat). Jakarta : Erlangga. Kriyantono, Rachmat. 2006. Teknik Praktis Riset Komunikasi. Jakarta: Kencana.

Lankow, Jason. 2012. Infographics: The Power of Visual Storytelling. New York: Columbia University.

M.A., Morissan. 2008. Manajemen Public Relations: Strategi Menjadi Humas

Profesional. Jakarta: Kencana.

Nasution. 2003. Metode Penelitian Kualitatif. Bandung: Tarsito. Oxlade, Chris. 2014. Environment Infographic. London: British Library.

Ritchie, J. dan Lewis. J. 2003. Qualitative Research Practice: A Guide for Social Science Students and Researchers. London: Sage Publications.

Rukajat, A. 2018. Manajemen Pembelajaran. Yogyakarta: Deepublish.

Smiciklas, Mark. 2012. The Power of Infographics: Using Picture to Communicate and Connect with Your Audiences. United States of America: Pearson Education.

\section{Website}

Pertanian Hortikultura. 2019. Diakses terakhir pada tanggal 24 Juli 2019. http://hortikultura.pertanian.go.id/?page_id=7 
T-sciences, 2014, diakses terakhir pada tanggal 12 Juli 2019, http://www.t- sciences.com/news/humans-process-visual-data-better

\section{Ministry of Laws and Regulations}

Permentan 20 Tahun 2016 Uraian Pekerjaan Unit Kerja Eselon IV Peraturan Presiden Republik Indonesia Nomor 15 tahun 2005

Peraturan Menteri Pertanian Nomor: 299/Kpts/OT.140/7/2005 jo 11/Permentan/OT.140/2/2007 Peraturan Menteri Pertanian Nomor: 341/Kpts/OT.140/9/2005/12/Permentan/OT.140/2/2007. 1. Introduction 